TEI

OURNAL OF THE TEXT ENCODING INITIATIVE

\section{Journal of the Text Encoding Initiative}

Issue 11 | July 2019 - June 2020

Selected Papers from the 2016 TEI Conference

\title{
Biography as Compilation: How to Encode Georg Nikolaus Nissen's Biographie W. A. Mozart's (1828) in TEI P5
}

Anja Morgenstern and Agnes Amminger

\section{CpenEdition}

\section{Journals}

Electronic version

URL: http://journals.openedition.org/jtei/2725

DOI: 10.4000/jtei.2725

ISSN: 2162-5603

Publisher

TEl Consortium

Electronic reference

Anja Morgenstern and Agnes Amminger, « Biography as Compilation: How to Encode Georg Nikolaus Nissen's Biographie W. A. Mozart's (1828) in TEI P5 », Journal of the Text Encoding Initiative [Online], Issue 11 | July 2019 - June 2020, Online since 16 January 2020, connection on 01 July 2020. URL : http:// journals.openedition.org/jtei/2725; DOI : https://doi.org/10.4000/jtei.2725

For this publication a Creative Commons Attribution 4.0 International license has been granted by the author(s) who retain full copyright. 


\section{Biography as Compilation: How to Encode Georg Nikolaus Nissen's Biographie W. A. Mozart's (1828) in TEI P5}

Anja Morgenstern and Agnes Amminger

ABSTRACT

The project of editing the early Biographie W. A. Mozart's (1828) by Georg Nikolaus Nissen (Nissen Online) began as part of the Digital Mozart-Edition (DME) at the Mozarteum Foundation Salzburg. The aim of the edition is to reveal the structure of the text by identifying the diverse sources Nissen relied on when writing the biography. These include primary sources such as original letters and documents from the Mozart family, secondary sources such as contemporary literature about Wolfgang Amadeus Mozart, and original text written by the author and later editors. Considering the challenges that arise when creating an edition that tries to define the different strands of a text, this paper describes how XML/TEI markup was applied to

1. encode text passages which often do not correlate with common text structures (paragraphs, chapters); 
2. document different types of sources and their authors or editors; and

3. integrate a detailed bibliography of the sources as well as critical annotations for each single text passage.

\section{INDEX}

Keywords: digital edition, text encoding, source criticism, biography, Mozart

\section{The Biography}

1 The Biographie W. A. Mozart's, comprising two volumes totaling approximately one thousand pages, was written between 1824 and 1828 in Salzburg and published in early 1829 by Breitkopf \& Härtel in Leipzig (Nissen 1829a, 1829b). It was the first comprehensive biography of Mozart and utilized, for the first time on a large scale, about four hundred letters of the Mozart family. The author was Georg Nikolaus Nissen (1761-1826), a Danish diplomat and the second husband of Constanze Mozart (1762-1842), widow of the composer.

\subsection{Origination Process}

2 In the summer of $1824 \mathrm{Mr}$. and Mrs. Nissen visited Mozart's sister, Maria Anna von Berchtold zu Sonnenburg (1751-1829), in Salzburg. She presented them with the family correspondence and other original documents by Mozart. This gift inspired Nissen to start his work on a book about Wolfgang Amadeus Mozart.

$3 \quad$ Nissen studied the letters and made excerpts of passages he regarded as worth publishing. Up until early 1826 he collected and copied all published writings on Mozart. He compiled a bibliographical list of the works he had studied, which the editors later included in the biography. It contains more than eighty items, including the earliest German biographies of Mozart, Italian and French biographical articles, biographies of other musicians, the most important musical periodicals, musical and general encyclopedias, as well as music history books and many more items. However, Nissen and his successors did not properly cite the author or source of the majority of the texts they used. As a consequence, unattributed direct quotation from many sources constituted a kind of plagiarism. 
4 All the working material Nissen used for the main volume is preserved in the Library of the Mozarteum Foundation Salzburg and helps us to reconstruct his work on the biography. In addition to the letters, two early Mozart biographies form the basis of Nissen's biography: the necrology by Friedrich Schlichtegroll (Gotha 1793, offprint 1794) and the second edition of the Lebensbeschreibung des K. K. Kapellmeisters Wolfgang Amadeus Mozart by Franz Xaver Niemetschek, issued in 1808. These two publications, based on authentic material provided by Mozart's sister and widow, formed the framework for Nissen. A feature of this framework was the integration of numerous passages extracted from secondary sources.

5 Nissen died in March 1826 without leaving a publishable manuscript, and two other people were involved in completing his work. The first was Anton Jähndl (1783-1861), the Regens chori (choirmaster) of the Benedictine convent Nonnberg at Salzburg. While using the working material left by Nissen he prepared the manuscript for publication, sometimes adding documents and articles that had been published after March 1826, but also adding passages of his own. When this work was completed in the spring of 1828 , Constanze Nissen engaged the physician and Mozart enthusiast Johann Heinrich Feuerstein (1797-1850) at Pirna in Saxonia as the second editor of the manuscript. Feuerstein changed a great number of verbal expressions and added some of his own ideas as well.

\subsection{Assessment}

6 While some readers, among them Johann Wolfgang von Goethe and Felix Mendelssohn Bartholdy, appreciated the insights available from Mozart's letters published in Nissen's biography, several critical reviews of the book emerged in early 1829. The most important article was written by Ignaz Mosel (1772-1844), a music historian, and published in 1830 in Jahrbücher der Literatur. Mosel recognized all the plagiarized passages. His detailed analysis culminates in the following summary: "the major part of the book, or in fact-excluding the letters-the whole book consists of plagiarism"1 (Mosel 1830,164). He further characterizes the book as a "mix of copies, citations, and plagiarism without sensitivity, in random choice and order"' (Mosel 1830, 163). Some years later the Russian music writer Aleksandr Ulybyšev (1794-1858) and the philologist and music historian Otto Jahn (1813-1869) also became aware of the deficiencies in Nissen's biography, and 
both decided to write their own biographies of Mozart. In 1842-43 Ulybyšev published a biography in French in three volumes, and between 1856 and 1858 Jahn published a biography in German in four volumes.

7 Over the next 150 years, this critical assessment of the biography was forgotten, and the editors of the Neue Mozart-Ausgabe used it for the documentary volume Mozart. Die Dokumente seines Lebens (Deutsch 1961), without critical annotation. The importance accorded to Nissen's biography was based on the circumstance that the author was married to the widow of Mozart. The opinion that Nissen had firsthand information was expressed again by Rudolph Angermüller in his new edition of the biography (Nissen 2010). It contains many annotations on people and works, but completely abstains from analyzing and commenting on the secondary sources used by Nissen on a large scale, even though in 1997 Dieter Demuth had already stated that Nissen's biography of Mozart wasapart from the letters-a true plagiarism of early Mozart literature and that the detection of all of Nissen's sources remained a desideratum (Demuth 1997, 83).

\subsection{Research Results}

8 The detailed analysis of Nissen's biography revealed that the hypothesis of firsthand information is by no means valid. Nissen used secondary sources even for biographical details about Mozart. All aesthetic considerations of Mozart's music are unattributed quotations taken from other authors. Nissen sometimes put together contradictory statements or contrasting aesthetical positions, such as classical and romantic ideas about Mozart's music, without critical reflection. Constanze Mozart's contribution to the biography consists only of details of little importance (Morgenstern 2014, 103-9).

9 Although Nissen's biography reproduced texts and worklists of other authors on a large scale, the book offered, besides the important Mozart correspondence, some original documents, unknown portraits of Mozart and his family, musical pieces from the so called Nannerl Notebook, as well as a specimen of Mozart's handwriting. The list of unfinished musical compositions by Mozart was completely new to the musical world at this time as well. For a few Mozart letters, where the originals are lost today, the biography is the only known source. 


\section{The Digital Edition}

Our project is part of the Digital Mozart-Edition at the Salzburg Mozarteum Foundation. Its goal is to fill a gap in Mozart research by analyzing the Nissen biography to distinguish and elucidate its various sources:

- $\quad$ primary sources (such as Mozart letters and original documents),

- $\quad$ secondary sources (early Mozart literature, newspapers, encyclopedias, etc.), and

- original texts (texts written originally by Nissen, Jähndl, or Feuerstein).

11 The choice of an appropriate encoding method was determined by the aim of covering as many results of this analysis as possible. Regarding the individual text passages, the results of the research-or rather the information to be conveyed by the online edition-can be outlined by the following questions: Is the text passage in question based on a primary or a secondary source, or was it originally written by one of the biography's editors? For primary and secondary sources: What is the exact source or reference? And, finally: Which one of the editors is responsible for inserting each passage into the biography?

12 The base TEI XML file, containing the text of the biography as well as basic structural markup-for instance, for headings, paragraphs, and graphically highlighted text-was created by converting a Microsoft Word document via the TEI's OxGarage tool (https://oxgarage.tei-c.org). ${ }^{3}$ The encoding mode, hereafter described in detail, is based on the TEI P5 and on categories determined and described by ourselves in compliance with the TEI, either within the XML document itself or in the corresponding schema file. ${ }^{4}$ In order to assign and add certain information, we reference resources provided externally, like digitized texts or authority files.

Our schema is a subset of the TEI. We started with an all-encompassing TEI schema, ${ }^{5}$ customizing it mainly by deleting elements and attributes, and by adding closed lists of attribute values to other elements. The values are described in prose within the schema file or in the document itself. This was the case with the subsections of the bibliography (see section 2.2) and the listing of the editors (see section 2.1.3). While the former merely introduces project-specific terms (e.g., "primary" and "secondary") to classify sources, the latter covers the circumstance of editors contributing to a text 
in a manner not explicitly taken into account by the TEI, namely by tacit text reuse. ${ }^{6}$ The referenced descriptions are also meant to be displayed, for example in order to provide additional information when a certain passage is clicked, and thus also serve a purpose besides the documentation.

\subsection{The Encoding}

\subsubsection{Segmentation According to Sources}

14 The first step in the process of source-related encoding was the segmentation of the text in accordance with the biography's composition process. Since the biography is made up of passages from many different sources, each passage from a distinct source should be marked up and be recognizable as such. However, these passages do not always correlate with paragraphs; in some cases, a passage of this kind might even stretch from inside a paragraph to the middle of the next one. The tree structure of the format-related markup is overlapped by a stream of text passages as illustrated in figure 1: 
Figure 1. Page 652 of the printed biography; the first passage in grey comprises the first and part of the second paragraph.

652

menza di Tito, welche am 5ten September auf's Theater kam. In der Mitte dieses Monats reis'te er nach Wien zurück und schrieb ein paar Tage vor der Vorstellung der Zauberflöte, die am 30sten September 1791 geschah, die beste seiner Ouverturen und den herrlichen Priestermarsch zu Anfange des zweyten Actes der Zauberflöte am 28sten September.

Solcher Beyspiele könnțen mehre angeführt werden. Sein ausserordentliches Gedächtniss zeigte sich auch schon in der Jugend; das aufgefasste Miserere in Rom giebt hiervon einen vollen Beweis. Er behielt es ungeschwächt bis an sein Ende. Es hat sich gefunden, dass, als Burney viel später dieses Miserere nach einer Copie des Originals öffentlich bekannt machte, auch nicht eine Note anders als bey Mozart darin war.

Da man seine Compositionen unglaublich suchte: so war er nie sicher, dass ihm nicht ein neues Werk selbst während des Copirens abgestohlen wurde. Er schrieb daher bey seinen Clavier-Concerten gewöhnlich nur eine Zeile für eine Hand auf, und spielte das Uebrige aus dem Gedächtnisse. So hat er einst ein Clavier-Concert, welches er schon seit geraumer Zeit nicht in Händen gehabt hatte, in einer musikalischen Akademie aus dem Gedächtnisse gespielt, indem er die Principalstimme in der Eile zu Hause gelassen hatte.

In seiner Akademie zu Leipzig spielte er zwey Concerte, das sanft heiter reizende aus $B$ dur mit den Variationen aus $G$ moll, und das glänzende, prachtvolle aus $C d u r$, das nach seinem Tode heraus kam. In der Probe, wie am Concert-Abende, hatte er 
Since the need to deal with overlapping structures in XML is obvious and indeed frequently encountered in text encoding, a great number of possible solutions have already been proposed. The TEI Guidelines list and discuss in detail multiple approaches, some of them requiring extensions of the TEI, while also mentioning non-XML-based and nonconformant techniques (TEI Consortium 2016, 20: "Non-hierarchical Structures"). ${ }^{7}$ This does not mean that complex structures could not be handled with "pure" TEI, and we never considered an extension or a non-XML-based approach necessary because we mainly deal with a relatively simple case of just two overlapping hierarchies, one being merely a series of passages without any nesting or further overlapping. Generally, the goal of keeping the markup as intelligible as possible for the encoder, while sticking with only one file in order to keep control of the material, played a major role in settling for one of the proposed TEI-conformant approaches. This precluded the use of stand-off markup (TEI Consortium 2016, 20.4: "Stand-off Markup"), ${ }^{8}$ which involves both an extension and the necessity of encoding the two conflicting layers in different places or files. In the end we favored "Boundary Marking with Empty Elements" (TEI Consortium 2016, 20.2) ${ }^{9}$ over "Fragmentation and Reconstitution of Virtual Elements" (TEI Consortium 2016, 20.3), ${ }^{10}$ the former having the advantage that only the boundary points between the alternating text passages from different sources have to be marked up. The latter, on the other hand, requires that each fragment of every passage (the fragmentation being a result of the conflicting formal hierarchy) needs to be enclosed by its own tag, which, depending on the position of the passages in relation to the paragraphs, might result in a lot more markup. As can be seen in example 1, every boundary point between the different passages is marked by an empty milestone-like element (<anchor $>$ ). Each <anchor> element is given an @xml : id comprising the incipit of the following passage. Often, but not always, the boundary point of a passage matches an already existing boundary, for example between two paragraphs. If that is the case, the <anchor $>$ element is placed in between the paragraphs.

After the marking of the boundary points, another empty element (<span>) is inserted for every passage (see example 1). Each <span> references a text passage by pointing to the <anchor $>$ before it (using @from for this purpose) and to the <anchor> after it (using @to): ${ }^{11}$

Example 1. <span> elements defining text passages by referencing <anchor> elements (excerpt from page 652).

<anchor xml:id="anch1002_p651_Die_Musik"/> 


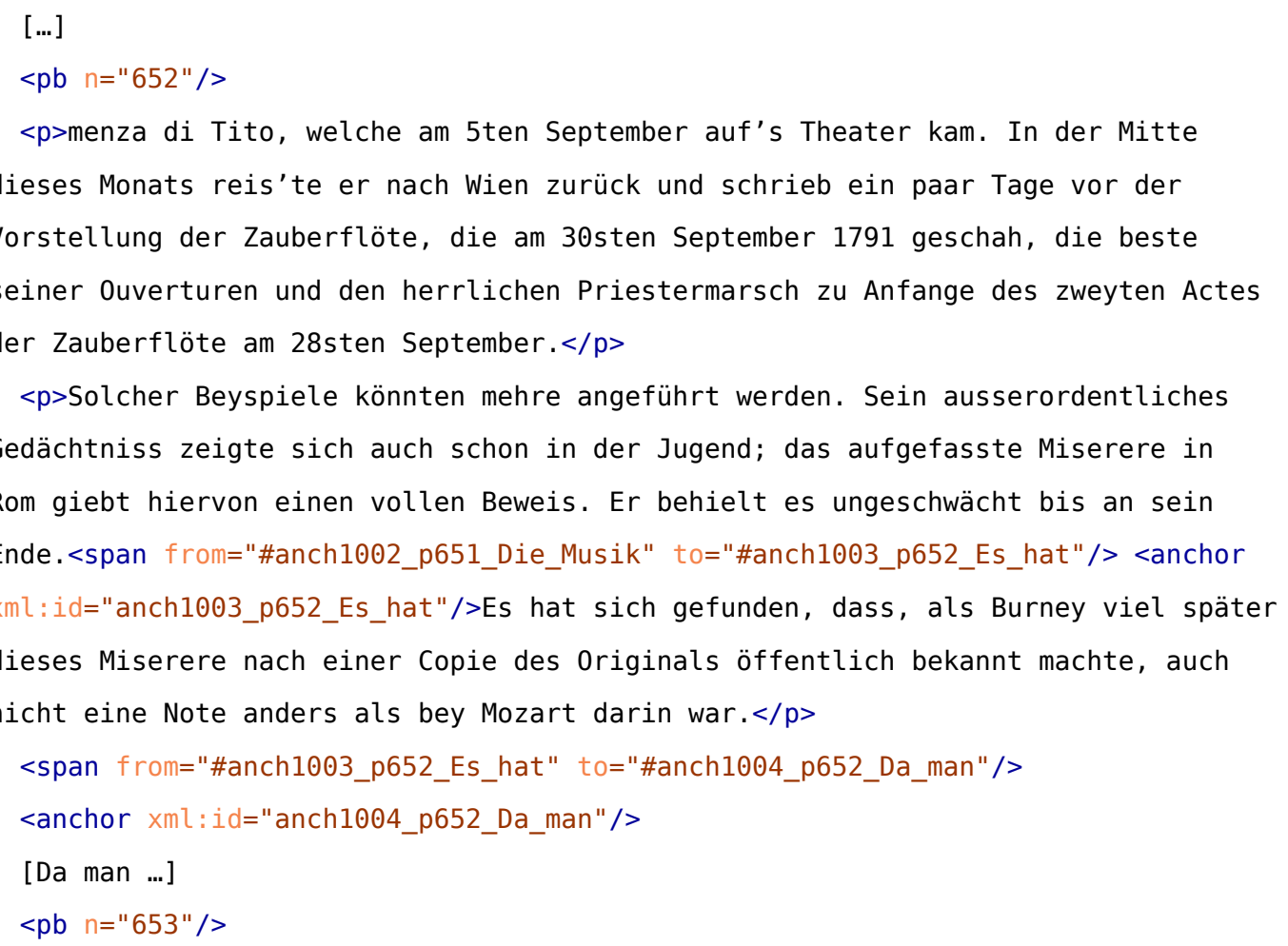

17 The <span> elements do not necessarily need to be positioned as shown above; another possibility is putting them into a <spanGrp> elsewhere within the document. However, it helps the encoder to have the <span> elements as close as possible to the text passages they refer to, since more information regarding a given passage will be added there later.

The TEI Guidelines do express some concern about processing data encoded with empty elements to mark boundary points between passages: "since the elements of the analysis ... [in our case the text passages] are not uniformly represented by nodes in the document tree, they must be reconstituted by software in an ad hoc fashion, which is likely to be difficult and may be error prone" (TEI Consortium 2016, 20.2: "Boundary Marking with Empty Elements"). ${ }^{12}$ However, the <span> elements referencing the text passages can easily be addressed. Difficulties arise when the passages-that is, the text streams themselves-need to be addressed, but the <span> elements, which reference unambiguously the beginning and end point of a particular portion of text, are of great advantage. The need to address a text passage as a stream arises, for example, during a search for all passages with a certain quality or attribute as text, or if every text passage on a certain page 
of the book is to be displayed in a different color when rendering the text with an appropriate web application. At this point, the development of the tool for online presentation is just beginning, so it remains to be seen how easy the markup will be to process.

\subsubsection{Documentation of Specifications}

Not only does the <span> element, as it is used in our encoding scheme, represent and reference passages or parts of text within a document; it also serves the purpose of associating "an interpretative annotation directly with a span of text" (TEI Consortium 2016, 17.3: "Spans and Interpretations"). ${ }^{13}$ Although <span> elements can have textual content, we decided to use <span> as an empty element with attributes since the annotations we want to add either are limited to only a few options (e.g., indicating which editor is responsible for the insertion of a given passage) or simply consist of a reference to an object encoded elsewhere (the bibliographic records of the sources that have been used). Therefore, there is no need for a prose description in either case since both specifications of the <span> element can easily be addressed using attributes and their values:

\section{Example 2. <span> element with all attributes.}

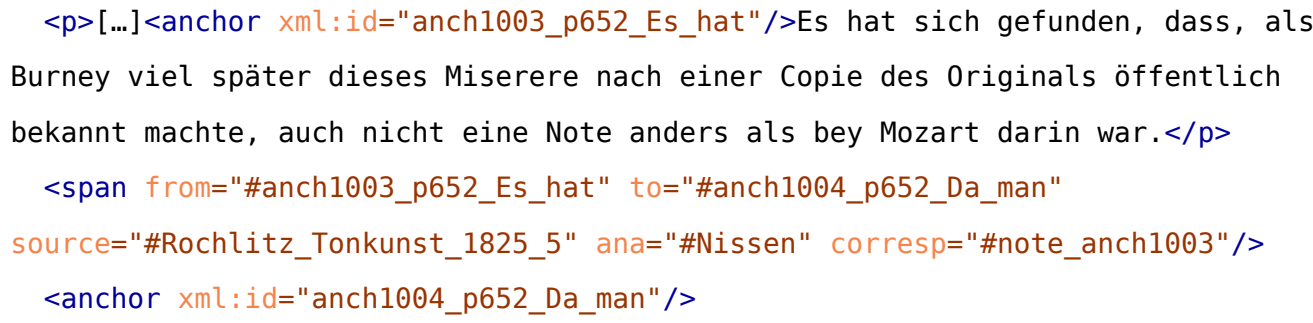

20 The elements referenced by the values of the attributes, i.e., @ana, @source, and @corresp, are documented within the same TEI XML file.

\subsubsection{Editors}

21 The value of @ana targets a <category $>$ element within a <taxonomy $>$ element. The <taxonomy $>$ element is enclosed by a <classDecl $>$ element, which is part of the encoding description (<encodingDesc $>$ ). The categories were established during the preceding examination and the analysis of the editors' preserved working materials as well as the text of the biography itself.

\section{Example 3. Documentation of the editors within a taxonomy.}

<classDecl>

$<$ taxonomy resp="\#AM"> 


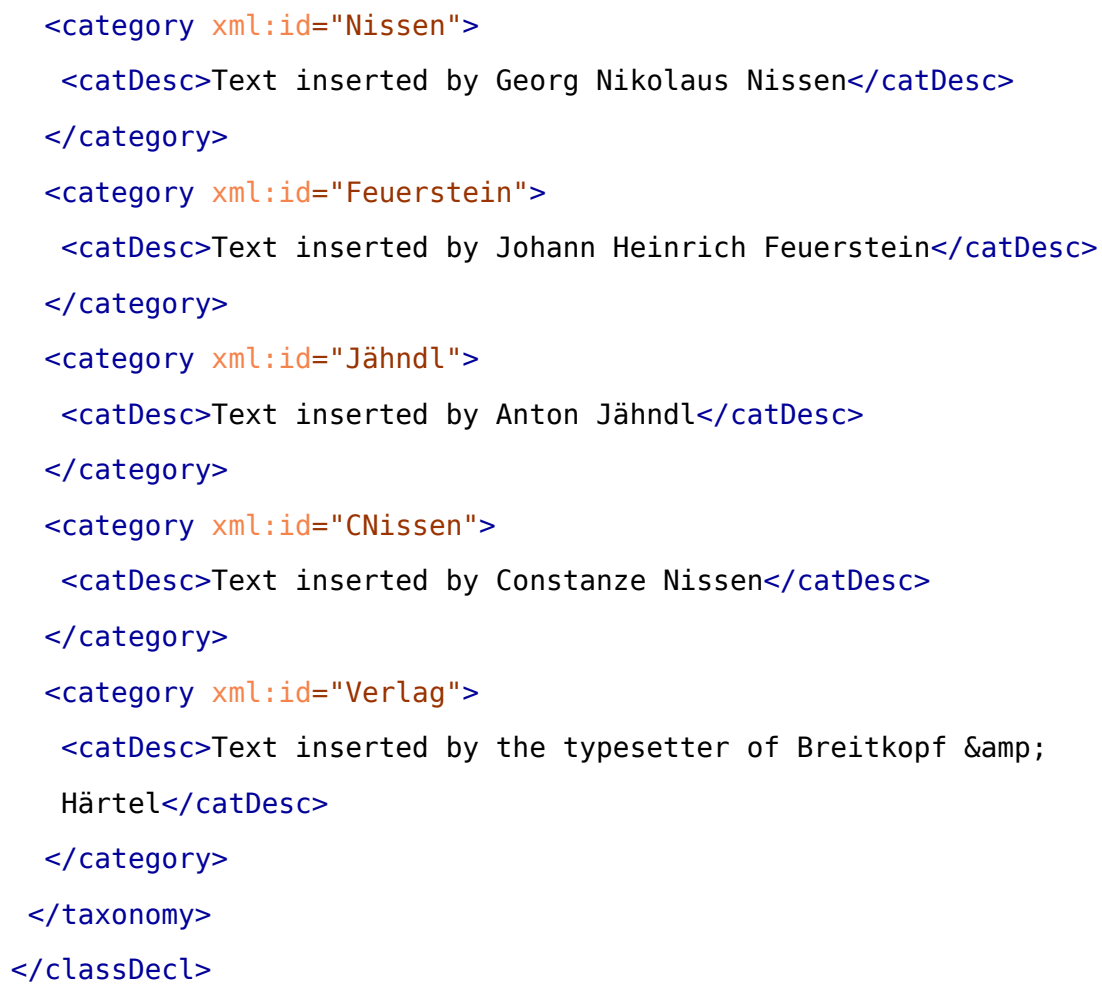

\subsection{Source References}

The many textual sources integrated into the biography are represented in the edition as structured bibliographic citations encoded in TEI. The element $<$ biblStruct $>$ is used to represent these citations. Please note the <citedRange $>$ elements at the end of example 4 :

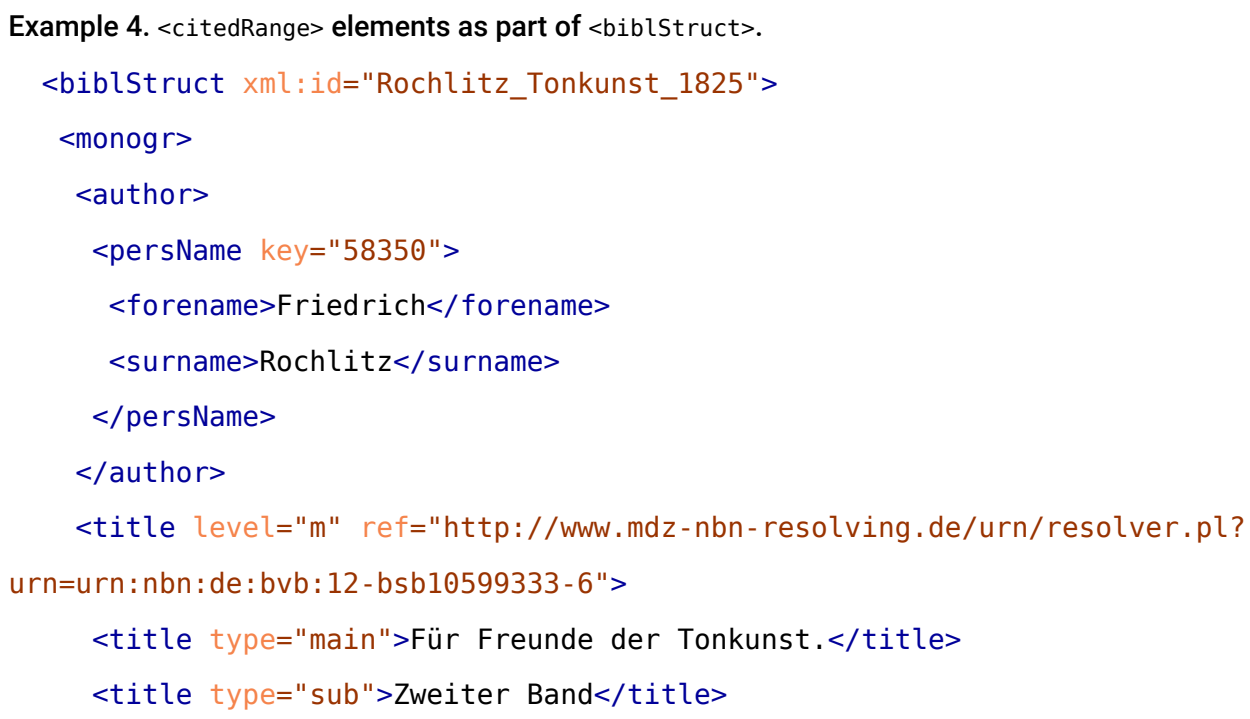




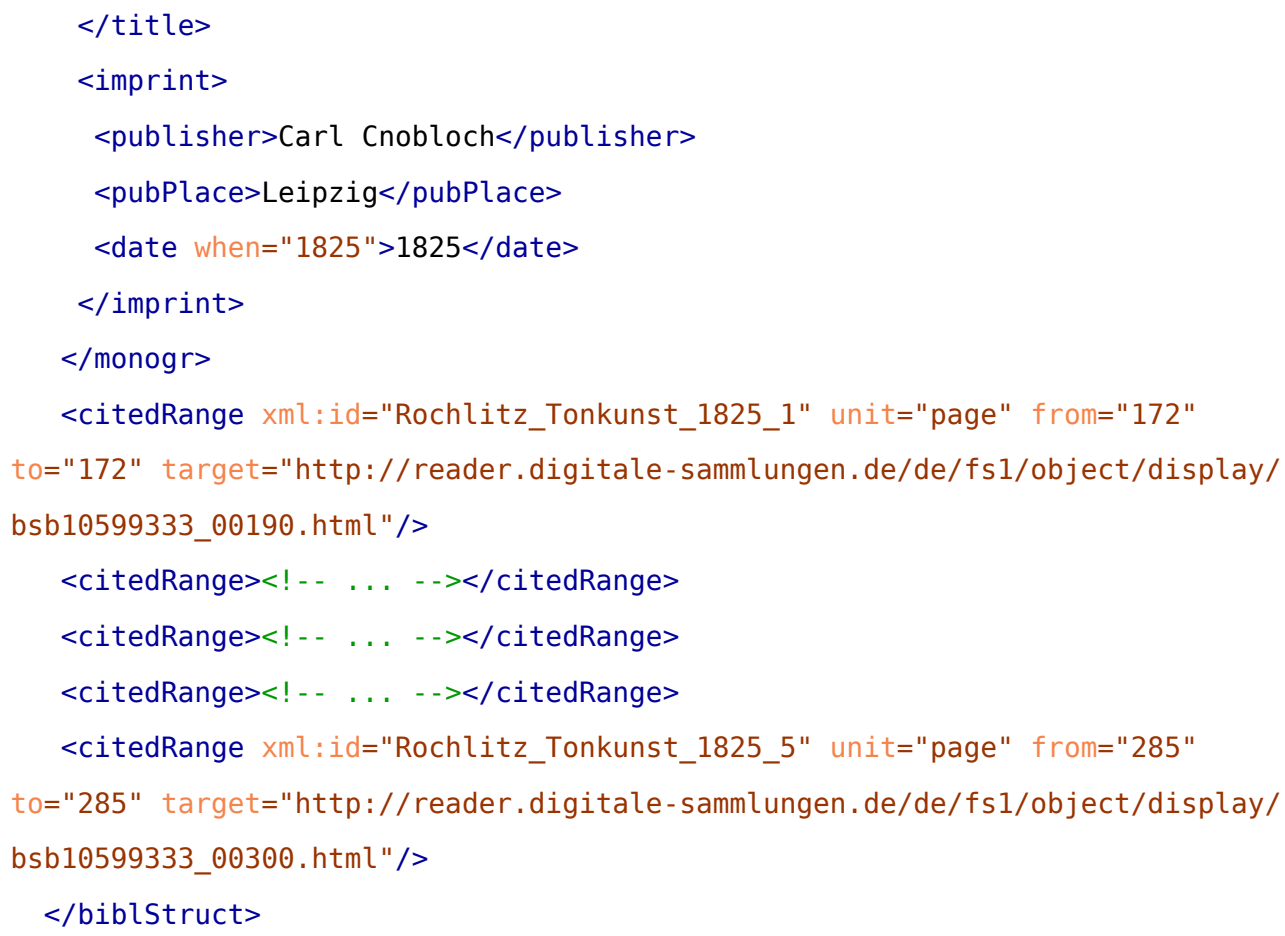

23 Each $<$ citedRange $>$ element indicates a page (or range of pages) containing text material reused by the editors of the biography. One coherent piece of reused text corresponds to exactly one <citedRange> element, which means that in cases where a certain work is cited (or rather plagiarized) more than once, several <citedRange> elements are listed. Each <citedRange> element is associated with the corresponding text passage within the biography. The mechanisms of associating ${ }^{14}$ elements and texts can be explained by looking at two examples given earlier: in example 2, the <span> element representing a reused text passage has a @source attribute, and this specific attribute points to a complete <citedRange> element in example 4.

24 This approach to encoding the original source of a text passage follows the standard procedure of citing from a traditional prose text: citation by page number. As such, it sufficiently serves its purpose. It could rightfully be argued, though, that in comparison to the exact identification of the passage within the biography itself, the rather generic reference to the source is somehow unsatisfactory. However, we do not have the resources to also encode in TEI all the texts that have been used in order to be able to point exactly to each sentence within its original context. ${ }^{15}$ The bibliography itself (encoded as $<$ listBibl $>$ ) is further divided into two sections, one as type=" primary", the other one as type=" secondary". The former contains all the primary sources, the latter the secondary sources: 
Example 5. Separate bibliographies for different types of sources (<biblstruct> elements stripped down).

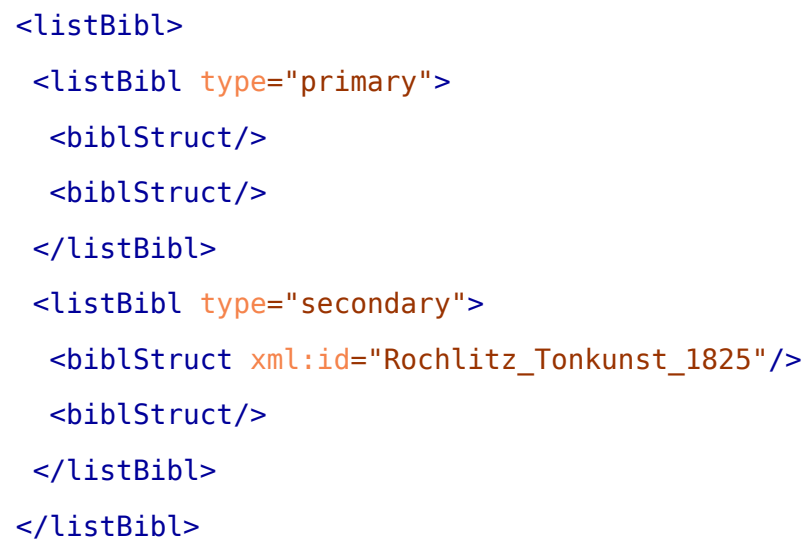

Since every bibliographical entry is part of either the first or the second $<$ listBibl>, the source type of every text passage within the biography is documented through the relationship with its corresponding bibliographical entry. The bibliography is organized like a taxonomy, and therefore serves the purpose not only of listing the sources that have been used but also of classifying and characterizing them further. The values of the @type attribute are documented in the corresponding schema.

27 If a passage was originally written by one of the editors and is thus not part of either a primary or a secondary source, but an original text, no @source is attached to the <span> element in question. In this case, the editor referenced by @ana is identical to the author of the text.

\subsubsection{Additional Remarks}

28 The responsible editor and the original source of a passage are represented by mechanisms that point toward further descriptive elements. Given that we might want to comment on a passage in a way that is not covered by the functions associated with these elements, an optional @corresp attribute pointing to a <note> element containing additional remarks is supplied within the respective <span>:

Example 6. <note> element for additional remarks.

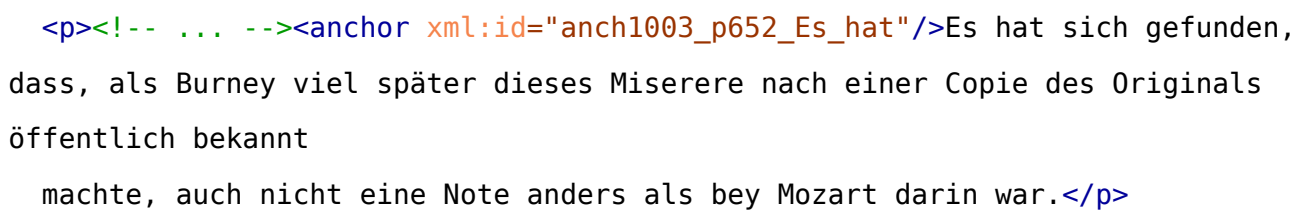




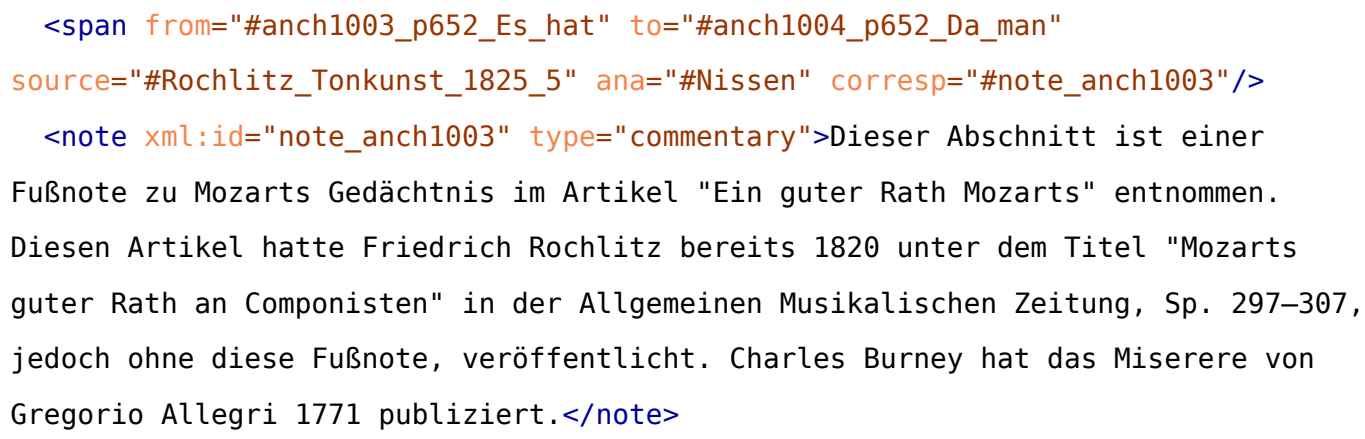

29 Only during the editing process do the <note> elements remain positioned as shown in example 6. In a second step, the notes will be listed in a $<$ list $>$ element of type="notes" which is part of the document's back matter. If they remained positioned between <anchor > elements, they would be part of the text passage represented and addressed by a <span> element, which would be semantically misleading since they are not part of the original text of the biography.

\subsubsection{Linking to Primary and Secondary Sources}

Nissen Online focuses on linking to the primary and secondary sources. The letters printed in the biography will be linked to the DME edition of letters and documents. ${ }^{16}$ This edition provides metadata and a diplomatic transcription of all Mozart letters, and displays digital images of the originals if they are in possession of the Mozarteum Foundation Salzburg.

Every text passage identified as a secondary source will be linked to an electronic resource. The digital collections of the Bibliotheca Mozartiana of the Mozarteum Foundation Salzburg already provide hundreds of sources as digital images, ${ }^{17}$ including books that were once part of Nissen's library. Furthermore, the digital collections of the Bavarian State Library and the National Library of Austria's digital portal ANNO (AustriaN Newspapers Online) ${ }^{18}$ offer digital resources that include a wide range of historical books, encyclopedias, and newspapers. Since not all of the digital portals offer permalinks for individual pages, the Persistent Uniform Resource Locator (PURL) for a digital resource as a whole is given within the <title $>$ element of the corresponding bibliographical entry (see example 4).

The integration of electronic images of the primary and secondary sources used by the three authors serves two purposes: 
1. Linking to electronic versions of the sources offers direct access to the original texts and allows comparison with the published texts in the biography. Nissen and Jähndl rewrote the plagiarized material slightly. Feuerstein, on the other hand, acted like a copy editor, restructuring sentences to a great extent and occasionally also changing individual phrases. It is not easy to determine whether Feuerstein did this in order to obscure the true provenance of the text or simply for reasons of style. In addition, the publisher Breitkopf \& Härtel modernized and standardized spellings, especially in the Mozart letters. The online edition focuses on the macro level of the text, revealing for the first time all the sources Nissen, Jähndl, and Feuerstein used for the Mozart biography. Due to its complex revision process, a complete encoding of all changes on a micro level is currently not part of the project. Cases of specific semantic alterations (e.g., the original phrase "himmlischer Genuss [heavenly pleasure]" was changed by Feuerstein to "herrlicher Genuss [marvelous pleasure]") will be documented with annotations by the editors.

2. The authors seldom used texts in full. Sometimes only one sentence on Mozart was taken from a long article primarily dealing not with Mozart but, for instance, with French opera history in general. Linking to electronic images of the sources allows the user to understand the context from which a phrase or paragraph was taken. Nevertheless, an additional commentary will discuss the source and its use in the biography (see section 2.2.1). Digital images of the working material are only presented in cases where it is the sole preserved source of otherwise lost documents, such as some of Mozart's letters.

\subsubsection{Indexing}

To index persons, names of places, and musical works, the project uses local databases of the Digital Mozart Edition (DME). Database entries relating to persons reference the authority file GND, ${ }^{19}$ if a listing is available. However, many people are mentioned in the Nissen biography for whom there still exists no GND record. Thus the DME, with its editors' profound knowledge on Mozart's contemporaries, has started generating GND records for scholars working in collaboration with the library Bibliotheca Mozartiana. Until this work is completed, it remains necessary to link to local databases. 
For the identification of places we reference the GeoNames authority files. ${ }^{20}$ Referencing authority files such as GND and GeoNames enables interchange between projects. The letter edition of the DME, which Nissen Online references, collaborates with correspSearch, ${ }^{21}$ a tool that allows one to search the metadata of various scholarly editions of letters.

\section{Conclusion}

Despite several critical evaluations in the nineteenth and twentieth centuries, many scholars in our days still cite the Nissen biography without being aware of the plagiarism inherent in it. This is the reason a critical edition is needed. Our online edition offers musicologists, and Mozart scholars in particular, a new, groundbreaking instrument for the critical study of the Nissen biography, with a focus on the documentation and presentation of the secondary sources used by its authors. These sources encompass most of the familiar writings on Mozart up to 1829, but also less well-known publications.

36 The outlined encoding method allows for numerous search functions to be applied to the text of the biography. It allows users to examine how much primary and secondary source material and how much original text the biography contains. It also makes it possible to retrieve the contributions of a specific editor-the text passages he inserted or wrote by himself. And since the sources are further defined through the taxonomic order of the bibliography, it is possible to search the biography for particular types of sources.

37 The making of Nissen's Biographie W. A. Mozart's is by no means an isolated case. Extensive utilization as well as copying of all available sources were common practices in the making of nineteenthcentury biographies (Klein 2009, 247). Therefore, the outlined considerations on how to encode Nissen's compilation in TEI P5 might also be of interest for future work on similar texts. 


\section{BIBLIOGRAPHY}

Berti, Monica, Bridget Almas, David Dubin, Greta Franzini, Simona Stoyanova, and Gregory R. Crane. 2014.

“The Linked Fragment: TEI and the Encoding of Text Reuses of Lost Authors." Journal of the Text Encoding Initiative 8. http://journals.openedition.org/jtei/1218; doi:10.4000/jtei.1218.

Demuth, Dieter. 1997. Das idealistische Mozart-Bild 1785-1860. Tutzing: Schneider.

Klein, Christian. 2009. Handbuch Biographie: Methoden, Traditionen, Theorien. Stuttgart: Metzler.

Deutsch, Otto Erich. 1961. Mozart, die Dokumente seines Lebens. Neue Ausgabe sämtlicher Werke: in Verbindung mit den Mozartstädten Augsburg, Salzburg und Wien, Serie 10, Supplement: Werkgruppe 34. Kassel: Bärenreiter.

Morgenstern, Anja. 2014. "Neues zur Entstehungsgeschichte und Autorschaft der Biographie W. A. Mozart's von Georg Nikolaus Nissen (1828/29)," Mozart-Jahrbuch 2012: 21-146.

Mosel, Ignaz Franz von. 1830. “Mozart's Biographie.” Jahrbücher der Literatur 49 (January-March), 161-211.

Niemetschek, Franz Xaver. 1808. Lebensbeschreibung des K. K. Kapellmeisters Wolfgang Amadeus Mozart, aus Originalquellen, [...]. Second ed. Prag: Herrl.

Nissen, Georg Nikolaus. 1829a. Biographie W. A. Mozart's: Nach Originalbriefen, Sammlungen alles über ihn Geschriebenen, mit vielen neuen Beylagen, Steindrücken, Musikblättern und einem Fac-simile. Leipzig: Breitkopf und Härtel.

1829b. Anhang zu Wolfgang Amadeus Mozart's Biographie: Nach Originalbriefen, Sammlungen alles über ihn Geschriebenen, mit vielen neuen Beylagen, Steindrücken, Musikblättern und einem Fac-simile. Leipzig: Breitkopf und Härtel.

-—-. 2010. Biographie W. A. Mozarts, edited by Rudolph Angermüller. Hildesheim: Olms.

Schlichtegroll, Friedrich. 1793. "Den 5. December. Johannes Chrisostomus Wolfgang Gottlieb Mozart," In Nekrolog auf das Jahr 1791. Enthaltend Nachrichten von dem Leben merkwürdiger in diesem Jahre verstorbener Personen 2. Vol. 2, Gotha: 82-112.

[Schlichtegroll, Friedrich.] 1794. Mozarts Leben, Graz: Joseph Georg Hubeck. 
TEI Consortium. 2016. TEI P5: Guidelines for Electronic Text Encoding and Interchange. Version 3.1.0. Last updated December 15. https://www.tei-c.org/Vault/P5/3.1.0/doc/tei-p5-doc/en/html/.

\section{NOTES}

1 German: “diese Plagiate machen den größten Theil des Buches, oder eigentlich-die Briefe abgerechnet-das Buch selbst aus."

2 German: "ohne Zartgefühl, ohne Wahl und ohne Ordnung zusammengeknetetes Volumen von Abschriften, Citationen und Plagiaten."

3 The file, including a transcription of the whole text, was provided by courtesy of Paul Corneilson from the Early Mozart Biographies Project of the Mozart Society of America (http:// mozartsocietyofamerica.org/embp/).

4 After the completion of the encoding process, the TEI XML file and the attached schema will be uploaded on GitHub. The edition itself will later go online as part of the Digital Mozart-Edition.

5 “All," TEI customization with all modules included, https://tei-c.org/guidelines/customization/ \#section-1; RELAX NG version, https://www.tei-c.org/release/xml/tei/custom/schema/relaxng/ tei_all.rng.

6 The use of aresp in association with <respStmt> describes only the agents working on a TEI file (TEI Consortium 2016, 1.3.1.1.4: "Sources, certainty, and responsibility"; TEI Consortium 2016, 11.3.2.2: "Hand, Responsibility, and Certainty Attributes").

7 https://www.tei-c.org/Vault/P5/3.1.0/doc/tei-p5-doc/en/html/NH.html.

8 https://www.tei-c.org/Vault/P5/3.1.0/doc/tei-p5-doc/en/html/NH.html\#NHSO.

9 https://www.tei-c.org/Vault/P5/3.1.0/doc/tei-p5-doc/en/html/NH.html\#NHBM.

10 https://www.tei-c.org/Vault/P5/3.1.0/doc/tei-p5-doc/en/html/NH.html\#NHVE.

11 In a different context, Martin Holmes suggested a similar approach on the TEI-L mailing list: https://listserv.brown.edu/cgi-bin/wa?A2=ind1302\&L=TEI-L\&D=0\&P=148629.

12 https://www.tei-c.org/Vault/P5/3.1.0/doc/tei-p5-doc/en/html/NH.html\#NHBM.

13 https://www.tei-c.org/Vault/P5/3.1.0/doc/tei-p5-doc/en/html/AI.html\#AISP.

14 Our thanks go to Peter Stadler, research assistant at the Carl-Maria-von-Weber-Gesamtausgabe, for suggesting this approach. 
15 For a non-XML-based, technology-independent approach to referencing exact portions of text, see the description of an implementation of CTS URNs by Berti et al. (2014).

16 Mozart Letters and Documents-Online Edition, accessed October 18, 2019, http:// dme.mozarteum.at/DME/briefe/doclist.php?l=2.

17 Digital Collections of the Bibliotheca Mozartiana, accessed October 18, 2019, http:// digibib.mozarteum.at/?lang=en.

18 ANNO-AustriaN Newspapers Online (Historische österreichische Zeitungen und Zeitschriften online), accessed October 18, 2019, http://anno.onb.ac.at/.

19 “The Integrated Authority File (GND)," accessed November 6, 2019, https://www.dnb.de/EN/ Professionell/Standardisierung/GND/gnd_node.html.

20 GeoNames geographical database, accessed November 6, 2019, http://www.geonames.org/.

21 Developed and operated by TELOTA (The Electronic Life of the Academy), Berlin Brandenburg Academy of Sciences and Humanities (BBAW), accessed November 6, 2019, https:// correspsearch.net/index.xql?id=\&l=en.

\section{AUTHORS}

\section{ANJA MORGENSTERN}

From 2001 to 2007 Anja Morgenstern was a research assistant at the Felix Mendelssohn Bartholdy Letters Edition Project at the University of Leipzig. Since 2007 she has been a member of the research staff of the Digital Mozart-Edition at the Mozart Foundation Salzburg, where she is responsible for the online edition of letters and documents of the Mozart family.

\section{AGNES AMMINGER}

Agnes Amminger is currently studying for a master's degree in German philology at the University of Salzburg. She has been a staff member of the Digital Mozart-Edition at the Mozart Foundation Salzburg since 2012. 